\title{
Tree species for sheltering hill pasture: some establishment results from a North Canterbury site
}

\author{
J.W . Sturrock \\ Crop Research Division, DSIR, Lincoln
}

ABSTRACT Species of Eucalyptus, Acacia, Robinia pseudoacacia, and 8 clonal derivatives of 3 species of hybrid cypresses were planted as a one-row shelterbelt on an exposed, unimproved and seasonally dry pasture in North Canterbury. Plots were single trees, replicated 4 times. The trial is located at $500 \mathrm{~m}$ altitude on a sunny, 30" slope exposed to north-west Föhn winds. Supplementary water, essential on such country, was applied initially to aid establishment. The performance of the 19 species and clones 4.5 years after planting is reported, based on survival, height growth, habit, and resistance to pests and diseases. Species are classed as 'acceptable', 'promising' and 'unsuitable', and include both tall (dominant) and complementary or 'infiller' shelter species. Currently, favourable species include Eucalyptus gunnil, E. nicholii and possibly E. tenuiramis as dominants, and Acacia floribunda and $\mathrm{x}$ Cupressocyparis leylandii 'Leighton Green' as infillers. The importance of management for successful establishment and maintenance of effective shelter is stressed.

Keywords shelter, drought, hill pasture, shelter tree species, tree clones, Eucalyptus species, Acacia species, Robinia pseudoacacia, $\mathbf{x}$ Cupressocyparis species, hybrid cypresses, shelter management

\section{INTRODUCTION}

Trees are needed in hill country for erosion control, protecting livestock and pasture, and landscape improvement. However, successful establishment and growth are frequently restricted by clitnate (including exposure), soil and aspect. Seasonal drought regularly affects eastern hill country in both islands.

Most pastoral hill country is treeless, and there is little information on suitable species. Ledgard \& Belton (1985) surveyed plantation-grown conifers between $450 \mathrm{~m}$ and $900 \mathrm{~m}$ altitudes in Canterbury, noting that less than $0.1 \%$ of the $1.8 \mathrm{~m}$ ha surveyed was in trees. Hathaway \& King (1986) reported a 5year study of Eucalyptus species at wide spacing on erosion-prone Wairarapa hill country. Agroforestry, with wide-spaced pines, has found favour in situations where a progressive decrease in pasture growth from increasing shade is compensated for by satisfactory volume growth of trees and profitable sale of timber.

However, in many hill situations blanket tree planting is inappropriate for various reasons. The Report of the National Shelter Working Party included discussion of hill shelter and methods of integration with farming and advocated more research, including investigation into suitable tree species (King \& Sturrock 1984). For eastern hill country such species need to be very hardy, with resistance to drought, frost and wind damage and, in more southerly regions, snow damage. Species that are non-invasive in respect of seedling spread are preferred.

This paper reports the initial performance of some potentially suitable trees for sheltering exposed hill grassland using a conventional shelterbelt design and employing limited irrigation to aid tree establishment.

\section{SITE, MATERIALS AND METHODS}

The site, near Waikari in North Canterbury, is at $500 \mathrm{~m}$ altitude on a sunny, 30" slope of unimproved short-tussock grassland, predominantly Rytidosperma species/fescue-tussock. Exposure on the north-west aspect to Fohn winds increases the dryness, The soil is Tipapa hill, a freedraining yellow-grey earth of medium fertility, limited in productivity by drought. Annual rainfall is low and variable, giving a high drought expectation (Heine 1985). Annual rainfall over the four complete years (1985-1 988) of the trial averaged $700 \mathrm{~mm}$, ranging from $1004 \mathrm{~mm}$ in 1986 to $474 \mathrm{~mm}$ in 1988. At this site, Vartha et a/. (1982) recorded soil moisture below wilting point from late November to late February in 1979-80, but up to 5 months deficit per year can be expected (Cutler 1968).

The trial comprises six species of Eucalyptus, four species of Acacia, Robinia pseudoacacia, and three species of hybrid cypresses ( $\mathrm{x}$ Cupressocyparis), including some of their clones (Table 1). The 19 species and clones were planted late September 1984 as a one-row shelterbelt with single-tree plots in a semi-systematic, repeated sequence, the taller growing species alternated with lower growing ones to assess habit compatibility. Site restrictions limited the number of replications to four. Spacing was $1.75 \mathrm{~m}$. Pre-plant herbicide (SDA Permasol ${ }^{\circledR}$ ) was applied and weed control continued until the end of the second season. No fertiliser was given. Hand watering, about 5 litres 
per tree per occasion, was applied 8-10 times at the farmer's discretion over the first two seasons. Plant material came from DSIR, FRI and a local nursery, and was container-grown except Eucalyptus pulchella which was bare-rooted stock. Average height of species and clones at planting ranged from 16 to $20 \mathrm{~cm}$ in the wattles; 16 to $21 \mathrm{~cm}$ in hybrid cypresses; and 30 to $50 \mathrm{~cm}$ in the ecualypts, except $E$. pulchella and $E$. tenuiramis which averaged 60 $\mathrm{cm}$ and $70 \mathrm{~cm}$ respectively.

Eucalypt species were selected primarily on ability to resist drought, and include representatives from the peppermint, hardy gum and iron bark groups. E. gunnii, although unsuitable for the North Island because of insect damage, was included because it is very hardy and usually insect-free in the South Island.

Wattles, long valued for conservation, were selected for drought tolerance and potential value as complementary or 'infiller' species to taller growing species which tend with age to open up near their bases. The single deciduous species, Robinia pseudoacacia, was chosen because of its erosion control potential, with a fast growing root system.

The hybrid cypresses were included on the basis of previous trial work under mainly lowland conditions, and because they do not seed and spread to pasture.

Annual measurements/assessments were made of: tree height, form (habit), health, wind damage and survival. Stem diameter (50 $\mathrm{mm}$ above ground level) was measured in February 1989. Only the latest observations are reported here. Measured values were subjected to analysis of variance. On the basis of these measurements and observations species were classified as 'acceptable', 'promising' (warranting further study), and 'unsuitable'.

\section{RESULTS AND DISCUSSION}

Establishment of trees on steep sites where soil moisture is at or below wilting point for long periods is difficult even with good weed control. Despite occasional watering during the first two growing seasons, approximately $15 \%$ of trees died (Table 1). These were replaced to maintain shelter continuity, usually by the same species.

Table 1 gives tree dimensions 4.5 years after planting, with significant differences among species apparent, and Table 2 an assessment of overall performance. All species and clones show reduced growth $(\geqslant 50 \%)$ cf. that on moister lowland sites (e.g. Sturrock et al. 1986), the result of increased windiness, reduced average temperature and moisture shortage. The last factor is probably decisive. Ledgard \& Belton (1985) determined that $>75 \%$ of the variability of volume growth of pines in hill and high country was related to rainfall. Although altitude per se can reduce the incidence of pests and diseases, stress in trees from drought or infertile soils may exacerbate their effects (Ledgard $\&$ Belton 1985). So far, the general health of the trees is excellent; during the hot summer of $1988 / 89$ negligible leaf chewing on a few eucalypts and a

Table 1 Survival, mean height and mean stem diameter of species of Eucalyptus, Acacia, x Cupressocyparis and Robinia pseudoacacia, 4.5 years after planting

\begin{tabular}{|c|c|c|c|}
\hline Species and clones & $\begin{array}{r}\text { Tree } \\
\text { Losses' }\end{array}$ & $\begin{array}{r}\text { Height } \\
(\mathrm{cm})\end{array}$ & $\begin{array}{r}\text { Stem diam² } \\
(\mathrm{mm})\end{array}$ \\
\hline E. gunnii (ex Walduck Hunterston, Tasmania) & 0 & 385.5 & 66.5 \\
\hline E. tenuiramis (ex Walduck Lady Bay, Tasmania) & 1 & 315.0 & 70.5 \\
\hline E. nicholii (ex Victoria) & 0 & 229.0 & 61.0 \\
\hline E. pulchella (ex Lowburn) & 0 & 178.7 & 48.0 \\
\hline E. gracilis (ex Kershaw NSW) & 3 & 115.7 & 37.0 \\
\hline E. creba (ex Kershaw NSW) & 1 & 95.2 & 34.0 \\
\hline A. dealbata (ex Amberley House) & 0 & 275.0 & 74.0 \\
\hline A. floribunda (ex Kershaw NSW) & 0 & 198.2 & 73.5 \\
\hline A. rubida (ex Walduck Hunterston, Tasmania) & 0 & 178.0 & 45.5 \\
\hline A. cardiophylla (ex N.Z.F.S. Rangiora) & 1 & 134.0 & 32.0 \\
\hline x Cu. leylandii 'Leighton Green' & 2 & 208.0 & 39.5 \\
\hline x Cu. leylandii 'Haggerston Grey' & 0 & 178.5 & 37.5 \\
\hline x Cu. Ieylandii 'Stapehill' & 1 & 177.0 & 34.5 \\
\hline x Cu. leylandii 'Ferndown' & 0 & 166.6 & 35.0 \\
\hline x Cu. leylandii 'Green Spire' & & 139.7 & 23.5 \\
\hline x Cu. leylandii 'Naylors Blue' & 1 & 137.7 & 24.5 \\
\hline $\begin{array}{l}\text { x Cu. ovensii } \\
x \mathrm{Cu} \text {. clone } 850 / 329\end{array}$ & $\begin{array}{l}0 \\
1\end{array}$ & $\begin{array}{l}218.0 \\
170.0\end{array}$ & $\begin{array}{l}49.0 \\
29.0\end{array}$ \\
\hline $\begin{array}{l}\text { Robiniu pseudoacacia } \\
\quad \text { (ex FS } 2 / 0 / 83 / 15 \text { Te karaka) }\end{array}$ & 0 & 90.2 & 19.0 \\
\hline $\mathrm{SED}^{3}$ & & $35.4^{* *}$ & $9.8^{* *}$ \\
\hline
\end{tabular}

'Replacements excluded from the analyses

'Measured $50 \mathrm{~mm}$ above soil level

'Standard error of differences between means based on 4 replicates, significance levels apply to experiment grand means 
small infestation of mites on A. dealbata were noted.

As expected, the eucalypts generally made most growth (Table 1, Figure 1) forming the tall shelter. Best all-round species were E. gunnii and $E$. nicholii, with a good, but somewhat variable performance from E. tenuiramis (Table 2). E. pulchella did slightly less well than expected because it generally performs well in Canterbury (D. Franklin, pers. comm.) and was one of the best species in the Wairarapa trials (Hathaway \& King 1986).

Robinia pseudoacacia showed much variation in growth and overall ranked poorly. Improved varieties are in FRI trials (Krijgsman 1989).

Of the four wattles, A. floribunda did best as a relatively low-growing, shrub-like, infiller species producing good foliage cover to ground level (Figure 1). A. rubida, reputedly very frost tolerant, is sparser foliaged and barer at the base. A. dealbata is the most vigorous but loses its lower foliage, leading to ground droughts.

Most of the hybrid cypresses grew satisfactorily with all showing to various degrees some windsweep to their branches. In harsh conditions, as at this site, these species are likely to be useful infiller trees rather than providing tall shelter and as such will restrict shading of pasture. All show very good tolerance of drought, including 'Stapehill' (syn. Stapehill 20), allegedly the only drought-sensitive clone of Leyland cypress ( $x$ Cupressocyparis Ieylandii: Cupressus macrocarpa Chamaecyparis nootkatensis), a fact now dispute: by the evidence from this and other trials (Sturrock 1989). Good Leyland clones here include 'Leighton Green' (in spite of the failure of two plants in the original planting), probably the most adaptable clone, 'Haggerston Grey' and 'Ferndown' (syn. Stapehill 21) (Figure 1). Other clones and hybrids did less well, being slower growing and/or showing more marked asymmetric growth from wind influence. They include Leyland 'Naylors Blue', always the slowest clone to establish, but which might be expected to have enhanced drought and frost tolerances because of its glaucous needles; and $x \mathrm{Cu}$. ovensii (Ch. nootkatensis $x$ Cupressus lusitanica), very vigorous, but prone to wind damage to the leading shoot and upper developing branches. As infiller trees, branch distortion and loss of leader growth may not be too serious. However, the C. Iusitanica parent of Oven's cypress and an Arizona cypress parent of the hybrid clone 850/329 (Cupressus arizonica or C. glabra $x$ $C h$. nootkatensis) will preclude these two hybrids from coastal hills subject to strong salt-wind influence. It is evident, however, that the genetic variation within the $x$ Cupressocyparis should provide a choice of species and clones for a range of environments.

Only single provenances of other species have been used in this trial. Hathaway \& King (1986). although having insufficient numbers of trees to assess properly the variation within species, indicated that there were significant differences in height and insect damage in a number of eucalypts, including E. gunnii. Similarly, some strains of A. dealbata have improved growth rate and habit.

Some of the trees will soon require a little 'form' pruning, followed by 'pre-emptive' pruning (Maclaren \& Dean 1989) in the interests of minimising pasture shading and maintaining tree stability.

Management need not be onerous; much, including post establishment silviculture, will be done during the slacker winter months.

\section{CONCLUSIONS}

With the proviso that the work is restricted to one site over an initial 5-year period, with few plants, the

Table 2 Overall assessment of tree species at Waikari, North Canterbury after approximately 5 years.

\begin{tabular}{|c|c|c|c|}
\hline \multicolumn{4}{|c|}{ Class } \\
\hline \multirow[b]{2}{*}{ Tall shelter ${ }^{2}$} & Acceptable & Promising & Unsuitable \\
\hline & $\begin{array}{ll}\text { E. } & \text { gunnii } \\
\text { E. } & \text { nicholii }\end{array}$ & $\begin{array}{l}\text { E. tenuiramis } \\
\text { E. pulchella }\end{array}$ & E. gracilis \\
\hline \multirow[t]{4}{*}{ Complementary shelter ${ }^{4}$} & & & E. creba \\
\hline & $\begin{array}{l}\times \text { Cu. levlandii } \\
\text { 'Leighton Green' }\end{array}$ & $\begin{array}{l}\text { X Cu. leylandii } \\
\text { "Haggerston Grey' } \\
\text { 'Femdown' } \\
\text { 'Stapehill' } \\
\text { 'Green Spire' } \\
\text { Clone } 850 / 329\end{array}$ & $\begin{array}{l}\text { x Cu. leylandii } \\
\text { 'Naylors Blue' }\end{array}$ \\
\hline & A. Jloribunda & A. dealbata & $\begin{array}{l}\text { A. cardiophylla } \\
\text { A. rubida }\end{array}$ \\
\hline & & & R. pseudoacacia \\
\hline
\end{tabular}

'Based on growth, form, wind resistance and health

'Tall growing dominant species

Lower storey or infiller species, in the main 

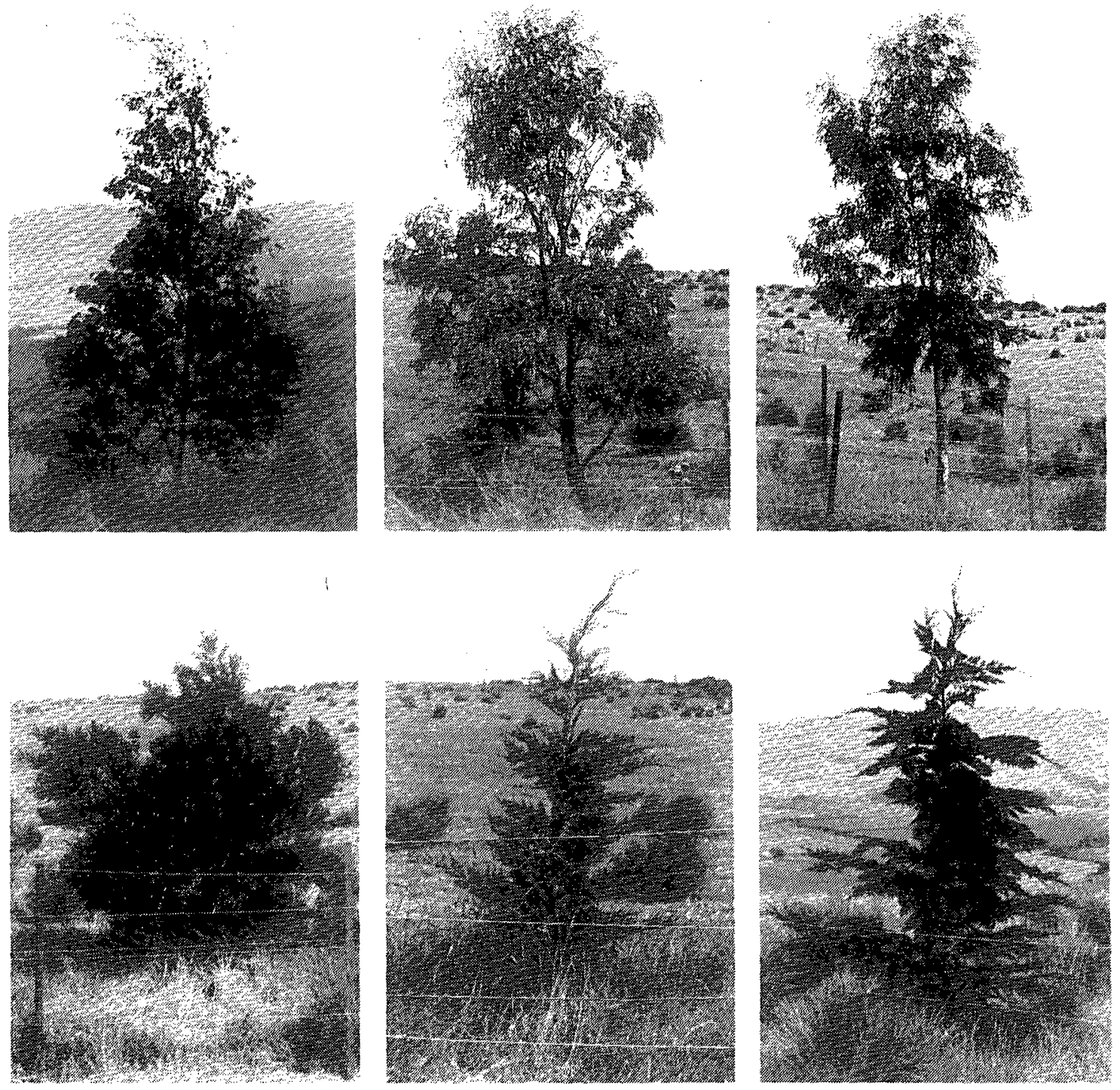

Figure 1 Some tree species at the Waikari hill site 4.5 years after planting. From left to right (top row): Eucalyptus gunnii; E. nicholii; E. tenuiramis. (bottom row): Acacia jloribunda; $\mathrm{x}$ Cupressocyparis leylandii 'Leighton Green'; $\mathrm{x}$ C. leylandit 'Ferndown'.

Photographs: J.W. Sturrock

results show that trees can be established in a hostile environment given appropriate species selection and management. Management may, as here, include occasional application of supplementary water during the crucial first one or two seasons to ensure tree establishment and survival. This practice, along with exemplary weed control, seems essential in situations with critically dry soils, and falls within the principle that a small planting well managed to prevent tree loss is preferable to a larger planting indifferently managed in which a high and unacceptable loss of trees occurs. Trickle irrigation, a re-useable resource, has an obvious role here and should ensure virtually $100 \%$ tree survival, given correct species choice.

Several of the hybrid cypresses appear valuable for hill shelter. These non-invasive conifers extend the range of compatible, infiller species. Such species are important shelter components, especially for livestock protection, given the greater wind strengths and relatively slower height gain of shelterbelts on exposed hills.

There is a need to evaluate other trees, including indigenous species, for shelter as well as provenance variation within species, preferably over a range of hill environments. 
Acknowledgements To P. Lamb on whose farm the trial was conducted; R. Vickers, DSIR, for technical assistance, E. Stevenson, DSIR, for statistical analyses; and to D. Eaves, Amberley House Nursery and D. Franklin, FRI, for advice on selection of some of the species.

\section{REFERENCES}

Cutler. E.J.B. 1968. Soils. In: general survey of the soils of the South Island, New Zealand. Soil Bureau Bulletin 27, NZ. DSIR: $17-74$

Hathaway, R.L.; King, M. 1986. Selection of Eucalyptus species for soil conservation bląnting in seasonallv dry hill country. NZ Joumal of Forestry Science $16(2): 142-151$

Heine, R.W. 1985. Climate and meteorological aspects of New Zealand's water resources. NZ Agricultural Science 19(4):152-156.
King, M.; Sturrock, J.W. 1984. Shelter and the hill country environment. In: J.W. Sturrock (ed), Shelter research needs in relation to primary production. Report of the National Shelter Working Party. Water and Soil Miscellaneous Publication 59:37-52.

Krijgsman, O.R. 1989. Robinia pseudoacacia $\ldots$ the improved Hungarian varieties. NZ Tree Grower $10(1): 19-20$.

Ledgard, N.J.; Belton, M.C. 1985. Exotic trees in the Canterbury high country. NZ Journal of Forestry Science 15(3): 298-323.

Maclaren, P.; Dean, M. 1989. Does it pay to form prune your pines? NZ Tree Grower $10(1): 12-13$.

Sturrock, J.W. 1989. The Stapehill Leyland cypresses. NZ Tree Grower 10(2): 18- 19.

Stunock, J.W.; Smail, P.W.; Vickers, R. 1986. New hybrid cypresses evaluated. NZ Tree Grower 7(4): 92-93.

Vartha, E.W.; Archie, W.J.; Archer, A.C.; Hoglund, J.H. Macmillan, B.H. 1982. Management of grassland on the sunny aspect of North Canterbury dry hill country: environment and quantity and quality of herbage. NZ Journal of Agricultural Research 25:475-483. 